\title{
Dynamics of Demand for Index Insurance: Evidence from a Long-Run Field Experiment
}

\section{Citation}

Cole, Shawn A., Daniel Stein, and Jeremy Tobacman. "Dynamics of Demand for Index Insurance: Evidence from a Long-Run Field Experiment." American Economic Review: Papers and Proceedings 104, no. 5 (May 2014): 284-290.

\section{Published Version}

https://www.aeaweb.org/articles?id=10.1257/aer.104.5.284

\section{Permanent link}

http://nrs.harvard.edu/urn-3:HUL.InstRepos:12534953

\section{Terms of Use}

This article was downloaded from Harvard University's DASH repository, and is made available under the terms and conditions applicable to Open Access Policy Articles, as set forth at http:// nrs.harvard.edu/urn-3:HUL.InstRepos:dash.current.terms-of-use\#OAP

\section{Share Your Story}

The Harvard community has made this article openly available.

Please share how this access benefits you. Submit a story.

Accessibility 


\title{
Dynamics of Demand for Index Insurance: Evidence from a Long-Run Field Experiment
}

\author{
By Shawn Cole, Daniel Stein, AND JeREMy Tobacman*
}

\begin{abstract}
* Cole: Harvard Business School and NBER, Soldiers Field, Boston, Massachusetts, 02163 (scole@hbs.edu). Stein: The World Bank, 1818 H Street NW, Washington DC, 20433 (dstein@worldbank.org). Tobacman: University of Pennsylvania and NBER, 3620 Locust Walk, Philadelphia, PA 19104 (tobacman@wharton.upenn.edu). We are very grateful to Chhaya Bhavsar, Nisha Shah, Reema Nanavaty, and their colleagues at SEWA, whose extraordinary efforts made this research possible. Maulik Jagnani, Laura Litvine, Dhruv Sood, Sangita Vyas, Will Talbott, Nilesh Fernando, and Monika Singh provided excellent research assistance. We would also like to thank USAID's BASIS program, 3ie, IGC, and Wharton's Dean's Research Fund for financial support. All errors are our own.
\end{abstract}

In the past ten years, many practitioners and academics have embraced micro-insurance. Economists view risk diversification as one of the few readily available "free lunches," and dozens of products were launched in the hopes of developing a financial service that was both welfare enhancing and economically sustainable. A successful market-based approach, however, requires consumers to make good decisions about whether to purchase products. Practically speaking, because marketing policies is expensive, sustainability may depend on high purchase and repurchase rates.

From a consumer perspective, making optimal insurance decisions requires a high degree of sophistication. Consumers must correctly estimate the probability distribution over a wide range of states of the world and imagine alternative coping mechanisms which may be available in unfamiliar scenarios. These difficulties are likely to be even more pronounced with novel financial products, such as rainfall index insurance, whose payouts depend on readings at local rainfall stations rather than consumers' actual losses. Reactions to others' experience may also be an important determinant of the commercial success of these products.

This paper examines the development of a new insurance market in detail, using a 7-year panel of rainfall insurance purchase decisions made by rural farming households in Gujarat, India. We characterize the evolution of takeup rates. We show that demand is highly sensitive to payouts being made in a household's village in the most recent year: a payout of Rs 1,000 (ca. USD 20, or roughly 5 days wage labor income) increases the probability households purchase insurance in the next year by $25-50 \%$. This effect is robust to controlling for crop losses, suggesting that insurance experience, rather than weather 
shocks, drives increased purchasing. This effect is stronger when more individuals in a village receive payouts. However, there is little additional effect of a household actually receiving a payout in the most recent season, once we condition on village payouts. This suggests that information generated by insurance payouts has village-wide effects.

We also explore the effects of insurance payouts over a longer time period. We find the effects of payments being made in a village remain positive over multiple seasons, but the estimated size decreases over time. In the most recent year, a household's receipt of an insurance payout does not have an additional effect beyond payments being made in the village, but longer-lagged household payout experience (two and three years before the current purchase decision) does have a strong positive effect on the purchasing decision.

These results stand in contrast to standard rational models, in which the realization of recent insurance outcomes should not affect forward-looking insurance decisions. Our findings from rural India are consistent with the findings by Kunreuther et al. (1985) and Brown \& Hoyte (2000), who study earthquake insurance purchases and flood insurance purchasers, respectively. Gallagher (forthcoming) examines a long-term community-level panel of flood insurance coverage in the US, and finds that insurance demand increases after a recent flood, but this effect decreases over time. In developing country contexts, Karlan et al. (2013) show, in a two-year panel, that rural Ghanaians are more likely to purchase if they or people in their social networks received payouts in the previous year. In contrast, Hill \& Robles (2011), studying rainfall index insurance in Ethiopia, find weakly negative effects of insurance payouts on future purchasing. Dercon et al. (2014) and Mobarak \& Rosenzweig (2013) study how insurance demand interacts with existing informal insurance arrangements, while Cai \& Song (2013) compare the impacts of hypothetical scenarios and recent disaster experience on weather insurance demand. Perhaps most closely related to our work is Stein (2011), which uses a three-year panel of rainfall insurance sales in southern India to estimate strong effects of receiving insurance payouts but limited spillover effects.

This paper represents the first attempt we are aware of to study the dynamics of demand for a product in which learning may be important, over a long time period (seven years), with randomized shifts in demand. Our richer data allow us to separately identify the dynamic effects of living in a village where payouts are made from the effects of an 
individual actually receiving payouts. The effect of living in a village with payouts is strongest in the subsequent season, while the individual-level effect of receiving a payout is strongest after two or three years.

\section{Experimental Setting}

For the study, a Gujarat-based NGO, the Self-Employed Women's Association (SEWA) marketed rainfall insurance to residents of 60 villages over a seven-year period from 2006-2013. The rainfall insurance policies, underwritten by insurance companies with long histories in the Indian market, provided coverage against adverse rainfall events for the summer (“Kharif') monsoon growing season. Households must opt-in to repurchase each year to sustain coverage. A SEWA marketing team visited households in our sample each year in April-May to offer rainfall insurance policies.

Each year households in the study were randomly assigned marketing packages, which induced exogenous variation in insurance coverage. The offering varied from year to year, and included discounts, targeted marketing messages, and special offers on multiple policy purchases. The effects of these marketing packages on insurance purchasing at the start of the study period are described in Cole et al. (2013). In addition, from 2009 through 2013, we elicited households' willingness to pay for insurance using an incentive-compatible Becker-deGrootMarschak (BDM) mechanism, which both induces exogenous variation in take-up and yields high-resolution data on households' insurance demand. Further details of the marketing interventions can be found in the online appendix.

At the beginning of the project in 2006, SEWA introduced rainfall insurance in 32 villages in Gujarat. In 2007, access was extended to 20 additional villages. ${ }^{1}$ These 52 villages were randomly chosen from a list of 100 villages in which SEWA had a substantial preexisting operational presence. ${ }^{2}$ Within each study village, 15 households were surveyed, of which 5 were randomly selected SEWA members, 5 had previously purchased (other forms of) insurance from SEWA, and 5 were identified by local SEWA employees as likely to purchase insurance. Since take-up of insurance was expected to be low, those thought likely to purchase insurance were deliberately oversampled. In 2009, 50 households in each of 8 additional villages were added to the study. Cumulatively, the sample that has been surveyed and assigned to

\footnotetext{
1 Other than via SEWA's initiative, rainfall insurance has in practice been unavailable in the study area.

2 The other 48 villages serve as control villages for a parallel randomized controlled trial of the effects of rainfall insurance.
} 
receive insurance marketing by SEWA consists of 1,160 households in 60 villages. We restrict analysis in this paper to the balanced panel of households who remain available to receive both marketing and survey visits in each year after they are added to the project. This results in a main sample of 989 households and 5,659 household-years in which the current and once-lagged insurance coverage decision are observed.

The terms of the insurance coverage offered each year varied due to changes in the insurance market and SEWA's desire to offer the best possible coverage to its members as it learned about their rainfall-related risk. However, the coverage had certain stable features. It was written based on rainfall during the June-September Kharif growing season. Contracts depended upon daily rainfall readings at local rainfall stations, and specified payouts as a function of cumulative rainfall during fixed time periods. Conditions indicative of drought and flood were covered. The smallest indivisible unit of insurance, which we refer to here as a "policy," generally had a maximum possible payout of Rs 1500 . Households were free to purchase multiple policies to achieve their desired level of coverage. More details of the specific policies offered can be found in the online appendix.

\section{Data}

Our data are merged from two primary sources. Administrative information on insurance purchasing decisions was provided by SEWA. This includes the number of policies purchased and the Rupee amount of payouts disbursed. The second data source is an annual household survey. The survey has been extensive, but here we use it only to ensure that attrition is detected and to construct one useful covariate, the householdlevel crop loss experienced.

Each season, households were asked if they had experienced crop loss due to weather. If they answered yes, the amount of crop loss is calculated as the difference between that year's agricultural output and the mean value of output in all prior years where crop loss was not reported. Summary statistics for all variables are reported in the online appendix.

\section{Empirical Analysis}

\section{OLS Estimates}

Throughout this section we report estimates of regressions of an insurance purchase indicator on lagged measures of insurance experience. $^{3}$

\footnotetext{
3 This paper focuses on effects of the level of recent insurance payouts. Of course, optimal insurance decisions would be informed by the joint distribution of payouts and indemnities (i.e., crop losses).
} 
Table 1 considers separately the sample of insurance purchasers (i.e., those who had purchased in the previous year) and the sample of insurance non-purchasers (i.e., those who had not purchased in the previous year) to gain a simple view of direct versus spillover effects of past insurance payouts. Columns 1 and 2 consider the insurance purchasers, consisting of the 882 households who purchased insurance at least once over the years 2006-2012, with a total of 2085 household-year observations. Column 1 shows the OLS relationship ${ }^{4}$ between insurance purchase in the current year and the payout per policy in the previous year in the village (which depends only on the terms of the contract and measurements at the reference weather station). This regression (along with all that follow) includes household fixed effects and clusters standard errors at the village level. ${ }^{5}$ The coefficient on the Village Payout Per Policy is statistically and economically significant, implying that a payout per policy of Rs 1000 causes a 50 percentage point (p.p.) increase in the probability of purchasing insurance in the next season.

\footnotetext{
4 Throughout the paper, for simplicity, we report results from linear probability models.

${ }^{5}$ Robustness is extensively documented in the online appendix.
}

The actual payout received by a household is the payout per policy times the number of policies purchased. In Column 2 we add variables for the number of policies purchased in the previous year, the total payout received in the previous year, and three additional controls: Number of Households in Village who Received a Payout the Previous Year, the household's Revenue Lost Due to Crop Loss the Previous Year, and the Mean Revenue Lost Due to Crop Loss in the village the previous year. None of these variables enter significantly, and the coefficient on Village Payout Per Policy remains strong and significant.

In Columns 3 and 4 we turn to the nonpurchasers of insurance in order to concentrate on spillover effects. These regressions show that past insurance payouts have a strong effect even on people who had not purchased insurance, and this effect is stronger if more people in the village have received payouts. In Column 3, the coefficient suggests that an increase in payout of Rs 1000 leads to a 26 p.p. larger chance of purchasing insurance the following year among non-purchasers. The point estimates of the effect of insurance payouts are roughly twice the size of those for non-purchasers, but we cannot statistically reject their equality. 


\section{Analysis}

In this section we present the results for the combined sample. In the IV specifications, we instrument for the lag of the number of insurance policies purchased and the amount of payouts received using variables characterizing the lagged marketing packages and interactions of the lagged marketing packages with lagged insurance payouts.

Column 1 of Table 2 presents the primary IV specification. The coefficient on Village Payout Per Policy is large and significant, suggesting that an increase in payout by Rs. 1,000 results in a 29 p.p. increase in the probability of purchasing insurance the following year. The coefficient on the Individual Payout is positive, but not significantly different than zero. In Column 2 we include on the right-hand side the Number of Households in Village who Received a Payout the Previous Year, the individual household's Revenue Lost Due to Crop Loss the Previous Year, and the Mean Revenue Lost Due to Crop Loss in the village the previous year. The coefficient on the Number of Households in Village who Received a Payout the Previous Year is significant, implying that for each additional household receiving a payout, the probability of other villagers purchasing rises by 0.3 p.p. The Village Payout effect remains strong and significant. In sum, these IV results are largely consistent with the OLS results in Table 1. Insurance payouts have large effects on purchasing decisions in the following year.

\section{Longer-Term Effects}

We now exploit the panel's long duration. Figure 1 plots the coefficients of an IV regression which is the same as above, except that the purchasing decision is regressed on three lags of village and individual payouts. ${ }^{6}$ Consistent with our estimates above, the village payouts in the most recent year have a large effect while the additional effect of receiving a payout oneself is small. However, for two- and three-year lags the estimated effect of the village payout decreases, while the estimated effect of the individual payout increases. In the second and third year, the effects are statistically indistinguishable, meaning that the effects of payouts are around twice as large for those who actually receive them versus people who simply live in a village where payouts were made.

\footnotetext{
6 This distributed lag specification is restricted to the 3,861 observations where three lags are observed for the household. For comparability with the main IV results, we include the same set of right-hand-side controls, plus two additional lags of the Number of Policies Bought. Three lags of marketing package variables are used as exogenous instruments. For more details see the online appendix.
} 


\section{Discussion}

Taken together, the following patterns emerge. First, across almost all specifications there is a large and significant effect of having insurance payouts in a village on purchasing decisions the next year. This effect holds both for the insurance purchasers themselves (who received payouts) and the non-purchasers (who did not receive payouts). People are also more likely to purchase if many village coresidents received payouts in the previous year, a finding that is robust to controlling for revenue lost due to crop failure (which might have been expected to tighten liquidity constraints the following year). These results suggest that the transmission mechanism of the payouts is through dissemination of knowledge, as opposed to wealth or liquidity effects. By contrast, Stein (2011) concluded that the actual receipt of payouts was driving repurchase decisions.

When considering insurance purchasers and non-purchasers separately, we find the effect of insurance payouts in the previous year is roughly twice as large for the insurance purchasers. However, when considering the sample together and instrumenting for past household experience, the difference in effects decreases and is insignificant. The difference in these results may simply be due to noise: we cannot reject the hypothesis that the effects of payouts for purchasers and non-purchasers are the same. However, it is also possible that those whose purchases were caused by marketing packages behaved differently. The OLS results in Table 1 reflect the behavior of all insurance purchasers, of whom the compliers are a subset. That self-selected insurance purchasers are more likely to be affected by payouts is consistent with a form of "confirmation bias" among people with high demand for insurance. Receiving payouts makes them feel justified in their decision to purchase insurance (even at higher prices), and this drives future purchases. This effect is absent for people who were induced to purchase insurance by discounts and other marketing features.

The long-term results are more nuanced. We find that the effects of a village payout persist over three years, yet decrease in magnitude over time. This is consistent with the results of Gallagher (forthcoming), who shows that insurance purchasing is consistent with a Bayesian learning model only allowing for rapid forgetting about past disasters. Overinference from recent experience is another explanation for the data. Surprisingly, we find the additional effect of a household's own payout experience follows a different pattern. While the first lag of receiving a payout is small and insignificant, the effect of the 
second and third lags is large. The difference in lagged effects of witnessing a payout versus receiving one is curious and merits further investigation.

\section{Conclusion}

This paper provides new evidence about the evolution of demand for a promising but complicated micro-insurance product. We find that households in villages where insurance payouts occurred are much more likely to purchase in the following season. This effect persists for multiple seasons but decreases over time. We find that the additional effects of experiencing a payout oneself are small for the first season after the payouts are made, but are larger two and three seasons later. Overall, our results suggest some updating from insurance experience, with spillovers that are transmitted to non-purchasers of insurance.

These findings have mixed implications for the prospects of rainfall index insurance. Large spillovers can facilitate commercial expansion. However, over-inference from recent payouts (analogous to return-chasing with insurance viewed as an investment, c.f. Slovic et al. 1977) might distort individual decisions. High variance in the expansion rates of rainfall index insurance across time and space, depending on recent experiences, might also result. We hope this analysis can usefully complement and inform leading practical thinking about the public and private sector roles in agricultural insurance (Mahul, Clarke, Maher, \& Assah, 2013).

\section{References}

Browne, M., \& Hoyt, R. (2000). The Demand for Flood Insurance: Empirical Evidence. Journal of Risk and Uncertainty, 20(3), 291-306. Retrieved from http://dx.doi.org/10.1023/A\%3A1007823 631497

Cai, J., \& Song, C. (2013). Insurance Take-up in Rural China: Learning from Hypothetical Experience.

Cole, S., Gine, X., Tobacman, J., Topalova, P., Townsend, R., \& Vickery, J. (2013). Barriers to Household Risk Management: Evidence from India. American Economic Journal: Applied Economics, 5(1), 104-35. Retrieved from http://www.aeaweb.org/articles.php?doi $=10.1257 /$ app.5.1.104

Dercon, S., Hill, R. V., Clarke, D., Outes-Leon, I., \& Taffesse, A. S. (2014). Offering rainfall insurance to informal insurance groups: Evidence from a field experiment in Ethiopia. Journal of Development Economics , 106(0), 132-143. Retrieved from http://www.sciencedirect.com/science/ar ticle/pii/S0304387813001338

Gallagher, J. (forthcoming). Learning about an Infrequent Event: Evidence from Flood Insurance Take-up in the US. American Economic Journal: Applied Economics, 47. Retrieved from http://faculty.weatherhead.case.edu/jpg7 5/pdfs/flood_insurance_aeja.pdf 
Karlan, D., Osei, R. D., Osei-Akoto, I., \& Udry, C. (2012, October). Agricultural Decisions after Relaxing Credit and Risk Constraints. Working Paper, National Bureau of Economic Research. Retrieved from http://www.nber.org/papers/w18463

Kunreuther, H., Sanderson, W., \& Vetschera, R. (1985). A behavioral model of the adoption of protective activities. Journal of Economic Behavior and Organization, 6(1), 1-15. Retrieved from http://www.sciencedirect.com/science/ar ticle/B6V8F-46SX3VW2/2/cfe2c91eabe2f0ab2a24188b96e24a5 8

Mahul, O., Clarke, D., Maher, B., \& Assah, F. (2013). Promoting Access to Agricultural Insurance in Developing Countries. World Bank.

Mobarak, A. M., \& Rosenzweig, M. R. (2013). Informal Risk Sharing, Index Insurance, and Risk Taking in Developing Countries. American Economic Review, 103(3), 37580. Retrieved from http://www.aeaweb.org/articles.php?doi $=10.1257 /$ aer .103 .3 .375

Slovic, P., Fischhoff, B., Lichtenstein, S., Corrigan, B., \& Combs, B. (1977). Preference for Insuring against Probable Small Losses: Insurance Implications. The Journal of Risk and Insurance, 44(2), pp. 237-258.

Retrieved from http://www.jstor.org/stable/252136

Stein, D. (2011). Paying Preimums With The Insurer's Money: How Loss Aversion Drives Insurance Decisions in a Repeated Interaction. unpublished. 
Table 1: Effects of Payouts on Purchasers and Non-Purchasers

\begin{tabular}{|c|c|c|c|c|c|}
\hline & Insurance & Purchasers & $\begin{array}{r}\text { Inuran } \\
\text { Purcl }\end{array}$ & $\begin{array}{l}\text { ce Non- } \\
\text { hasers }\end{array}$ & \\
\hline & (1) & $(2)$ & (3) & (4) & \\
\hline Village Payout per Policy in Previous Year (Rs. '000s) & $0.504^{* * *}$ & $0.513 * *$ & $0.255 * *$ & 0.196 & * \\
\hline & $(0.139)$ & $(0.196)$ & $(0.107)$ & $(0.105)$ & \\
\hline Individual Payout Received Previous Year (Rs. '000s) & & -0.046 & & & \\
\hline & & $(0.046)$ & & & \\
\hline Number of Insurance Policies Bought Previous Year & & 0.014 & & & \\
\hline & & $(0.014)$ & & & \\
\hline Number of Households in Village who received a Payout Previous Year & & 0.003 & & 0.005 & $* * *$ \\
\hline & & $(0.002)$ & & $(0.002)$ & \\
\hline Revenue Lost Due to Crop Loss Previous Year (Rs. '0000s) & & -0.011 & & -0.004 & \\
\hline & & $(0.016)$ & & $(0.011)$ & \\
\hline Mean Village Revenue Lost Due to Crop Loss Previous Year (Rs. '0000s) & & 0.027 & & 0.063 & \\
\hline & & $(0.049)$ & & $(0.040)$ & \\
\hline Individal Fixed Effects & YES & YES & YES & YES & \\
\hline$\overline{R^{2}}$ & 0.167 & 0.171 & 0.187 & 0.196 & \\
\hline $\mathrm{N}$ & 2085 & 2085 & 3574 & 3574 & \\
\hline
\end{tabular}

Notes: The "Insurance Purchasers" sample is restricted to insurance purchasers at some point between 2006-2012, with households entering and exiting the sample each year based on their prior year insurance purchase decisions. This sample consists of 882 households who purchased insurance at least once. The "Insurance Non-Purchasers" sample is restricted to households who did not purchase insurance at some point between 2006-2012, with households entering and exiting the sample each year based on their insurance purchase decisions. This sample consists of 977 households, as 12 households purchased insurance in each year that it was available and are therefore always excluded. The dependent variable is a dummy for purchasing insurance in current year. All specifications include individual fixed effects, year dummies, dummies for when the household entered the experiment, and the complete set of same-year and previous year's marketing variables as additional controls. All specifications are OLS, and all standard errors are clustered at village level. Additional related specifications can be found in Tables A1 and A2 of the Online Appendix. 


\begin{tabular}{|c|c|c|c|}
\hline & \multicolumn{3}{|c|}{ Full Sample } \\
\hline & IV & \multicolumn{2}{|l|}{ IV } \\
\hline & (1) & $(2)$ & \\
\hline \multirow[t]{2}{*}{ Village Payout per Policy in Previous Year (Rs. '000s) } & $0.293 * * *$ & 0.266 & $* * *$ \\
\hline & $(0.092)$ & $(0.092)$ & \\
\hline \multirow[t]{2}{*}{ Individual Payout Received Previous Year (Rs. '000s) } & 0.114 & 0.09 & \\
\hline & $(0.079)$ & $(0.074)$ & \\
\hline \multirow[t]{2}{*}{ Number of Insurance Policies Bought Previous Year } & 0.00 & 0.001 & \\
\hline & $(0.010)$ & $(0.010)$ & \\
\hline \multirow[t]{2}{*}{ Number of Households in Village who received a Payout Previous Year } & & 0.003 & $* *$ \\
\hline & & $(0.001)$ & \\
\hline \multirow[t]{2}{*}{ Revenue Lost Due to Crop Loss Previous Year (Rs. '0000s) } & & -0.015 & $*$ \\
\hline & & $(0.008)$ & \\
\hline \multirow[t]{2}{*}{ Mean Village Revenue Lost Due to Crop Loss Previous Year (Rs. '0000s) } & & 0.035 & \\
\hline & & $(0.031)$ & \\
\hline Individual Fixed Effects & YES & YES & \\
\hline Cragg-Donald F-Stat & 26.24 & 25.899 & \\
\hline $\mathrm{R}^{2}$ & 0.166 & 0.17 & \\
\hline $\mathrm{N}$ & 5659 & 5659 & \\
\hline
\end{tabular}

Notes: Regressions include the full study sample of 989 households for all years in which they received insurance marketing. All specifications include individual fixed effects, year dummies, a dummy for the year in which a household entered the experiment, and the complete set of same-year marketing variables as additional controls. "Payout Recevied Previous Year" and "Number of Insurance Policies Bought Previous Year" are instrumented with the full set of marketing variables lagged one year, and the marketing variables interacted with village insurance payouts. All specifications are OLS, and all standard errors are clustered at village level. Additional related specifications can be found in Table A4 of the Online Appendix. 
Figure 1: Longer-Term Effects of Payouts

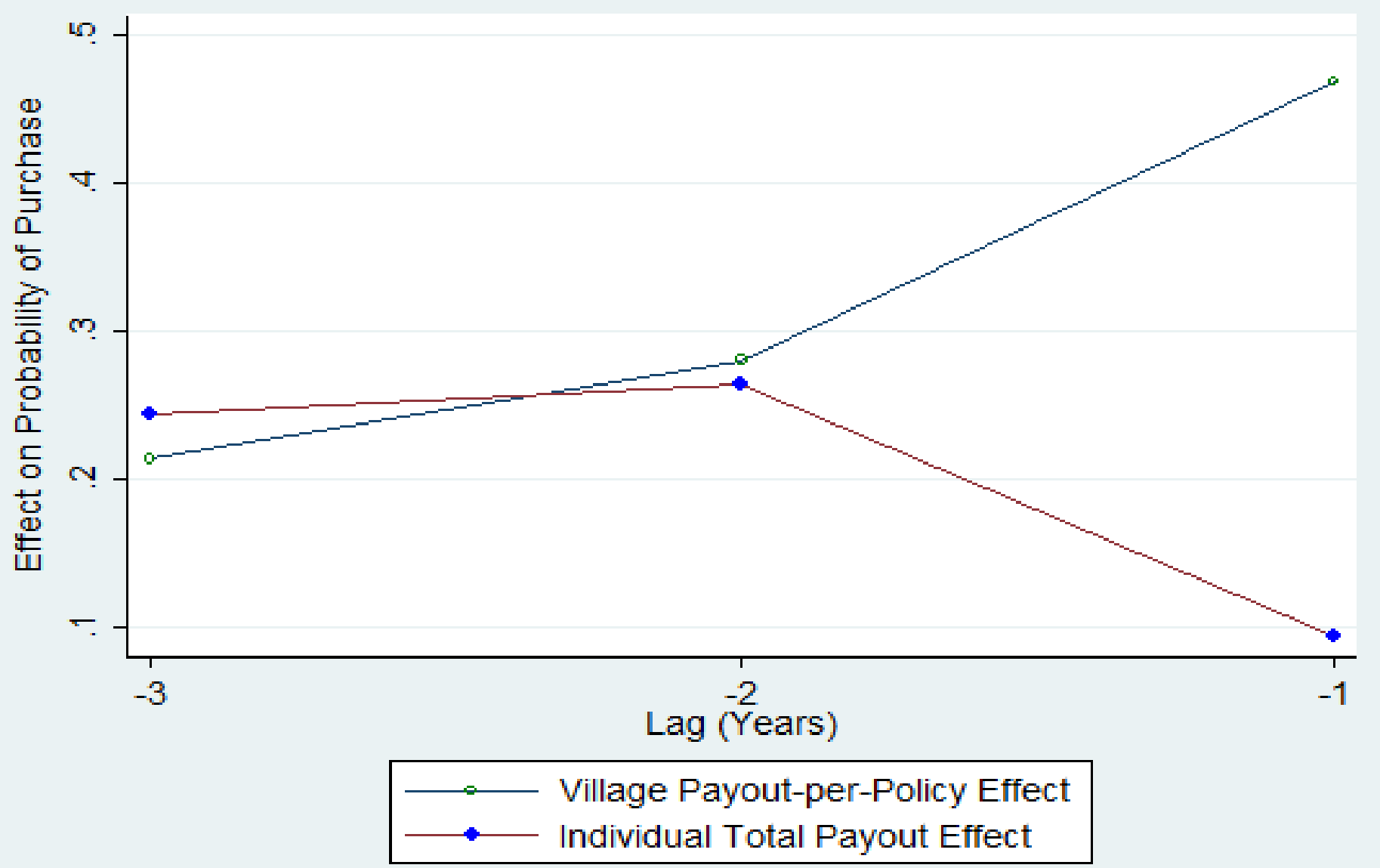

Notes: This figure plots the estimated effects on the insurance purchase probability of 3 lags of village-level payouts per policy and 3 lags of individual-level total payouts received, per 1000 Rupees of past payout. All estimates are significantly different than zero apart from the estimate on the first-year lag of individual payouts received. Estimates are drawn from specifications which instrument for past individual payouts with three lags of variables characterizing SEWA's randomly-assigned marketing packages, entered both directly and interacted with the village payout per policy. Regressions also include three lags of the number of insurance policies purchased (also instrumented), individual crop loss, and village average crop loss, as well as individual fixed effects, year dummies, a dummy for the year in which a household entered the experiment, and the complete set of same-year marketing variables. The sample is restricted to households that received insurance marketing for the three previous seasons before the current purchase decision. The regression table is presented in the Online Appendix Table A5. 
Online Appendix For:

\section{Dynamics of Demand for Index Insurance:}

\section{Evidence from a Long-Run Field Experiment}

Shawn Cole, Daniel Stein, and Jeremy Tobacman

American Economic Review: Papers and Proceedings

This online appendix contains the following items.

Appendix Table A1: Summary Statistics

Appendix Table A2: Repurchasing Decisions Among Insurance Purchasers

Appendix Table A3: Purchase Decisions Among Insurance Non-Purchasers

Appendix Table A4: Effects of Previous Insurance Experience on Full Sample

Appendix Table A5: Long Term Effect of Insurance Payouts

Appendix Table A6: Historical Average Insurance Experience

Appendix Table A7: Marketing Variables and Instruments

A8: Additional Details of Marketing Experiments

A9: Sample Insurance Policy Termsheets 


\section{Balanced Treatment Sample}

No. of households

No. of households (Lagged)

No. of villages

Take-up

Average market price per policy (Rs.)

Average price paid per policy (Rs.) (if purchased)

Average price paid per policy/market price (if purchased) (\%)

Purchase rate

No. of purchasers

No. of purchasers (Lagged)

No. of non-purchasers

No. of non-purchasers (Lagged)

Average policy units purchased (if purchased)

Re-purchasers

New purchasers

Quitters

Re-purchase rate (\%)

New-purchase rate (\%)

Quit rate (\%)

Payouts

Payout (yes/no)

Average payout (if purchased)

Average payout per policy (Rs.) (if purchased)

Average payout (if payout $>=$ Rs. 1)

Average payout per policy (Rs.) (if payout $>=$ Rs. 1)

Average number of people per village who received payouts (if village

payout per policy $>=$ Rs. 1

Crop Loss

Experienced crop loss (yes/no)

Average agricultural revenue lost per village due to crop loss (Rs.) (if payout $>=$ Rs. 1) $\begin{array}{lllllllll}405 & 649 & 649 & 989 & 989 & 989 & 989 & 989 & 6,648\end{array}$

$\begin{array}{llllllll}405 & 649 & 649 & 989 & 989 & 989 & 989 & 5,659\end{array}$

$\begin{array}{lllllllll}32 & 52 & 52 & 60 & 60 & 60 & 60 & 60 & 60\end{array}$

$\begin{array}{lllllllll}214 & 69 & 190 & 151 & 75 & 195 & 200 & 200 & 161\end{array}$

$\begin{array}{lllllllll}104 & 70 & 140 & 58 & 21 & 62 & 63 & 63 & 59\end{array}$

$\begin{array}{lllllllll}50 & 100 & 74 & 37 & 28 & 32 & 32 & 32 & 40\end{array}$

$\begin{array}{lllllllll}0.18 & 0.39 & 0.20 & 0.16 & 0.56 & 0.45 & 0.47 & 0.56 & 0.40\end{array}$

$\begin{array}{lllllllll}74 & 251 & 131 & 157 & 556 & 448 & 468 & 558 & 2,643\end{array}$ $\begin{array}{lllllllll}74 & 251 & 131 & 157 & 556 & 448 & 468 & 2,085\end{array}$

$\begin{array}{lllllllll}331 & 398 & 518 & 832 & 433 & 541 & 521 & 431 & 4,005\end{array}$ $\begin{array}{llllllll}331 & 398 & 518 & 832 & 433 & 541 & 521 & 3,574\end{array}$

$\begin{array}{lllllllll}1.03 & 1.02 & 1.07 & 2.33 & 4.52 & 2.16 & 1.96 & 1.99 & 2.40\end{array}$

$\begin{array}{llllllll}32 & 88 & 54 & 101 & 313 & 269 & 319 & 1176\end{array}$

$\begin{array}{lllllllll}- & 108 & 43 & 72 & 455 & 135 & 199 & 239 & 1,251\end{array}$

$\begin{array}{lllllllll}- & 42 & 163 & 77 & 56 & 243 & 179 & 149 & 909\end{array}$

$\begin{array}{lllllllll}- & 43 & 35 & 41 & 64 & 56 & 60 & 68 & 53\end{array}$

$\begin{array}{rlllllll}43 & 33 & 46 & 82 & 30 & 43 & 43 & 46\end{array}$

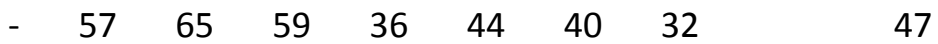

$\begin{array}{lllllllll}0 & 0 & 38 & 64 & 353 & 64 & 341 & - & 860\end{array}$

$\begin{array}{lllllllll}0 & 0 & 165 & 92 & 321 & 23 & 346 & - & 146\end{array}$

$\begin{array}{lllllllll}0 & 0 & 165 & 39 & 77 & 13 & 171 & - & 59\end{array}$

$\begin{array}{lllllllll}0 & 0 & 570 & 225 & 505 & 158 & 475 & - & 449\end{array}$

$\begin{array}{lllllllll}0 & 0 & 570 & 96 & 121 & 93 & 234 & - & \end{array}$

$\begin{array}{lllllllll}0 & 0 & 10 & 12 & 29 & 11 & 15 & - & 17\end{array}$

$\begin{array}{lllllllll}319 & 146 & 202 & 496 & 296 & 223 & 283 & - & 1,965\end{array}$

$\begin{array}{llllllll}0 & 0 & 2726 & 306 & 1856 & 421 & 1229 & -\end{array}$

$\begin{array}{lllllllll}0 & 0 & 2400 & 225 & 1882 & 473 & 1292 & - & 1227\end{array}$

Notes: This table reports summary statistics for the sample studied in this paper. In 2010, although the premium per policy was INR 150

Nabard was subsidising the policies with a 'buy one get one free' offer. This makes the equivalent price per policy INR 75 , and also explains the high number of policies purchased. 
Appendix Table A2: Repurchasing Decisions Among Insurance Purchasers

\begin{tabular}{|c|c|c|c|c|c|c|}
\hline & \multicolumn{3}{|c|}{ Pooled } & \multicolumn{3}{|c|}{ Individual Fixed Effects } \\
\hline & (1) & $(2)$ & (3) & (4) & (5) & (6) \\
\hline \multirow{2}{*}{ Village Payout per Policy in Previous Year (Rs. '000s) } & $0.864^{* * *}$ & $0.805^{* * *}$ & $0.692 * * *$ & $0.504^{* * *}$ & $0.592 * * *$ & $0.513^{* *}$ \\
\hline & $(0.122)$ & $(0.141)$ & $(0.142)$ & $(0.139)$ & $(0.190)$ & $(0.196)$ \\
\hline \multirow[t]{2}{*}{ Individual Payout Received Previous Year (Rs. '000s) } & & 0.027 & 0.011 & & -0.037 & -0.046 \\
\hline & & $(0.048)$ & $(0.046)$ & & $(0.047)$ & $(0.046)$ \\
\hline \multirow[t]{2}{*}{ Number of Insurance Policies Bought Previous Year } & & 0.016 & 0.019 & & 0.012 & 0.014 \\
\hline & & $(0.012)$ & $(0.012)$ & & $(0.015)$ & $(0.014)$ \\
\hline \multirow[t]{2}{*}{ Number of Households in Village who received a Payout Previous Year } & & & $0.003 *$ & & & 0.003 \\
\hline & & & $(0.002)$ & & & $(0.002)$ \\
\hline \multirow[t]{2}{*}{ Revenue Lost Due to Crop Loss Previous Year (Rs. '0000s) } & & & -0.002 & & & -0.011 \\
\hline & & & $(0.012)$ & & & $(0.016)$ \\
\hline \multirow[t]{2}{*}{ Mean Village Revenue Lost Due to Crop Loss Previous Year (Rs. '0000s) } & & & $0.067 *$ & & & 0.027 \\
\hline & & & $(0.034)$ & & & $(0.049)$ \\
\hline \multirow[t]{2}{*}{ Constant } & $0.317 * *$ & $0.300 * *$ & $0.297 * *$ & $0.406 * * *$ & $0.382 * * *$ & $0.380 * * *$ \\
\hline & $(0.134)$ & $(0.133)$ & $(0.133)$ & $(0.129)$ & $(0.132)$ & $(0.132)$ \\
\hline$\overline{r 2}$ & 0.169 & 0.17 & 0.176 & 0.167 & 0.167 & 0.171 \\
\hline $\mathrm{N}$ & 2085 & 2085 & 2085 & 2085 & 2085 & 2085 \\
\hline
\end{tabular}

Notes: Sample restricted to insurance purchasers from 2006-2012, with households entering and exiting the sample each year based on their insurance purchase

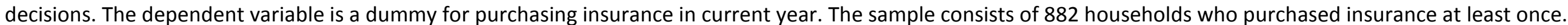
All specifications include year dummies, dummies for when the household's village first entered the experiment, and the complete set of same-year and previous year's marketing variables as additional controls. The Fixed Effects specifications include individual fixed effects. Variation in the fixed effects specifications is provided by the 505 households who purchased insurance more than once and experienced variation in the payouts received. All specifications are OLS, and standard errors are clustered at village level. Columns 4 and 6 are equivalent to columns 1 and 2 of Table 1 in the main text. 
Appendix Table A3: Purchase Decisions Among Insurance Non-Purchasers

\begin{tabular}{|c|c|c|c|c|c|c|}
\hline & \multicolumn{3}{|c|}{ Pooled } & \multicolumn{3}{|c|}{ Individual Fixed Effects } \\
\hline & $(1)$ & $(2)$ & $(3)$ & $(4)$ & $(5)$ & $(6)$ \\
\hline \multirow[t]{2}{*}{ Village Payout per Policy in Previous Year (Rs. '000s) } & $0.411^{* * *}$ & $0.359 * * *$ & $0.342 * * *$ & $0.255^{* *}$ & $0.209^{*}$ & $0.196 *$ \\
\hline & $(0.077)$ & $(0.079)$ & $(0.082)$ & $(0.107)$ & $(0.105)$ & $(0.105)$ \\
\hline \multirow[t]{2}{*}{ Number of Households in Village Who Received a Payout Previous Year } & & $0.003 *$ & $0.003 * *$ & & $0.005 * * *$ & $0.005 * * *$ \\
\hline & & $(0.002)$ & $(0.002)$ & & $(0.002)$ & $(0.002)$ \\
\hline \multirow[t]{2}{*}{ Revenue Lost Due to Crop Loss Previous Year (Rs. '0000s) } & & & -0.005 & & & -0.004 \\
\hline & & & $(0.006)$ & & & $(0.011)$ \\
\hline \multirow[t]{2}{*}{ Mean Village Revenue Lost Due to Crop Loss Previous Year (Rs. '0000s) } & & & $0.066 * *$ & & & 0.063 \\
\hline & & & $(0.029)$ & & & $(0.040)$ \\
\hline \multirow[t]{2}{*}{ Constant } & -0.043 & -0.043 & -0.042 & $0.651 * * *$ & $0.576 * * *$ & $0.568 * * *$ \\
\hline & $(0.063)$ & $(0.063)$ & $(0.063)$ & $(0.093)$ & $(0.081)$ & $(0.082)$ \\
\hline r2 & 0.182 & 0.185 & 0.186 & 0.187 & 0.195 & 0.196 \\
\hline$N$ & 3574 & 3574 & 3574 & 3574 & 3574 & 3574 \\
\hline
\end{tabular}

Notes: Sample restricted to households who did not purchase insurance from 2006-2012, with households entering and exiting the sample each year based on their insurance purchase decisions. The dependent variable is a dummy for purchasing insurance in current year. The sample consists of 977 households, as 12 households purchased insurance in each year that it was available and are therefore excluded. All specifications include year dummies, dummies for when the household entered the sample, and the complete set of same-year and previous year's marketing variables as additional controls. The Fixed Effects specifications include household fixed effects. Variation in the fixed effects specifications is provided by the 515 households who did not purchase insurance more than once and experienced variation in the payouts received. All specifications are OLS, and standard errors are clustered at village level. Columns 4 and 6 of this table correspond to Columns 3 and 4 of Table 1 in the main text. 
Appendix Table A4: Effects of Previous Insurance Experience on Full Sample

\begin{tabular}{|c|c|c|c|c|c|c|c|c|}
\hline & \multicolumn{2}{|c|}{ Pooled } & \multicolumn{2}{|c|}{ Individual Fixed Effects } & \multicolumn{2}{|r|}{ Pooled } & \multicolumn{2}{|c|}{ Individual Fixed Effects } \\
\hline & OLS & OLS & OLS & OLS & IV & IV & IV & IV \\
\hline & (1) & (2) & (3) & (4) & (5) & (6) & (7) & (8) \\
\hline \multirow[t]{2}{*}{ Village Payout per Policy in Previous Year (Rs. '000s) } & $0.459^{* * *}$ & $0.382 * * *$ & $0.307^{* * *}$ & $0.269 * * *$ & $0.437^{* * *}$ & $0.358^{* * *}$ & $0.293^{* * *}$ & $0.266^{* * *}$ \\
\hline & (0.079) & $(0.083)$ & (0.092) & $(0.092)$ & (0.079) & $(0.082)$ & $(0.092)$ & $(0.092)$ \\
\hline \multirow{2}{*}{ Individual Payout Received Previous Year (Rs. '000s) } & $0.102 * *$ & $0.078 *$ & $0.064 *$ & 0.045 & 0.096 & 0.047 & 0.114 & 0.09 \\
\hline & $(0.041)$ & $(0.039)$ & $(0.035)$ & $(0.033)$ & $(0.075)$ & (0.070) & $(0.079)$ & $(0.074)$ \\
\hline \multirow[t]{2}{*}{ Number of Insurance Policies Bought Previous Year } & $0.046^{* * *}$ & $0.045^{* * *}$ & -0.013 & -0.013 & 0.002 & 0.003 & 0.000 & 0.001 \\
\hline & $(0.007)$ & $(0.007)$ & (0.008) & $(0.008)$ & $(0.010)$ & (0.010) & $(0.010)$ & (0.010) \\
\hline \multirow{2}{*}{ Number of Households in Village who received a Payout Previous Year } & & $0.003 * * *$ & & $0.003 * *$ & & $0.004 * * *$ & & $0.003 * *$ \\
\hline & & (0.001) & & (0.001) & & (0.001) & & (0.001) \\
\hline \multirow{2}{*}{ Revenue Lost Due to Crop Loss Previous Year (Rs. '0000s) } & & -0.005 & & $-0.016 * *$ & & -0.005 & & $-0.015 *$ \\
\hline & & (0.005) & & (0.008) & & (0.005) & & $(0.008)$ \\
\hline \multirow[t]{2}{*}{ Mean Village Revenue Lost Due to Crop Loss Previous Year (Rs. '0000s) } & & $0.068 * * *$ & & 0.046 & & $0.07^{* * *}$ & & 0.035 \\
\hline & & $(0.024)$ & & $(0.034)$ & & $(0.025)$ & & $(0.031)$ \\
\hline \multirow[t]{2}{*}{ Constant } & $0.646 * * *$ & $0.617^{* * *}$ & $0.677^{* * *}$ & $0.632 * * *$ & 0.653 & $0.624 * * *$ & & \\
\hline & $(0.061)$ & (0.059) & $(0.061)$ & $(0.061)$ & $(0.046)$ & $(0.047)$ & & \\
\hline Cragg-Donald F-Stat & & & & & 30.549 & 30.048 & 26.242 & 25.899 \\
\hline r2 & 0.185 & 0.191 & 0.175 & 0.179 & 0.163 & 0.17 & 0.166 & 0.17 \\
\hline $\mathrm{N}$ & 5659 & 5659 & 5659 & 5659 & 5659 & 5659 & 5659 & 5659 \\
\hline
\end{tabular}

Notes: Regressions include balanced sample of 989 households. All specifications include year dummies, dummies for villages that entered the eperiment in different years, and the complete set of same-year marketing variables as additional controls. The OLS specifications also include the first lag of marketing variables as controls. In the IV Specifications, "Payout Recevied Previous Year" and "Number of Insurance Policies Bought Previous Year" are instrumented with the full set of marketing variables lagged one year, and the marketing variables interacted with village insurance payouts. Errors clustered at village level. Columns 7 and 8 correspond to Columns 1 and 2 of Table 2 in the main text. 
Appendix Table A5: Long Term Effect of Insurance Payouts

\begin{tabular}{|c|c|c|c|c|c|c|c|c|c|c|c|c|c|c|}
\hline & \multicolumn{3}{|c|}{ Pooled } & \multicolumn{3}{|c|}{ Individual Fixed Effects } & \multicolumn{4}{|c|}{ 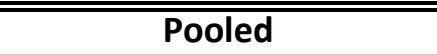 } & \multicolumn{4}{|c|}{ Individual Fixed Effects } \\
\hline & OLS & OLS & OLS & OLS & OLS & OLS & IV & & IV & & IV & & IV & \\
\hline & (1) & (2) & (3) & $(4)$ & (5) & (6) & (7) & & $(8)$ & & (9) & & (10) & \\
\hline Village Payout per Policy in Previous Year (Rs. '000s) & $0.504^{* * *}$ & $0.337^{* * *}$ & $0.369^{* * *}$ & $0.614^{* * *}$ & $0.509^{* * *}$ & $0.394^{* *}$ & 0.479 & ${ }^{* * * *}$ & 0.338 & ${ }^{* * * *}$ & 0.567 & *** & 0.469 & $* * *$ \\
\hline & $(0.088)$ & $(0.103)$ & $(0.103)$ & $(0.125)$ & $(0.145)$ & $(0.149)$ & $(0.098)$ & & $(0.110)$ & & $(0.131)$ & & $(0.148)$ & \\
\hline Village Payout per Policy Two Years back (Rs. '000s) & $\begin{array}{c}0.343 \text { *** } \\
(0.086)\end{array}$ & $\begin{array}{c}0.141 \\
(0.099)\end{array}$ & $\begin{array}{c}0.094 \\
(0.100)\end{array}$ & $\begin{array}{c}0.522^{* * *} \\
(0.125)\end{array}$ & $\begin{array}{l}0.423 * * * \\
(0.146)\end{array}$ & $\begin{array}{c}0.235 \\
(0.143)\end{array}$ & $\begin{array}{c}0.234 \\
(0.101)\end{array}$ & ** & $\begin{array}{c}0.059 \\
(0.110)\end{array}$ & & $\begin{array}{c}0.374 \\
(0.145)\end{array}$ & $* * *$ & $\begin{array}{c}0.280 \\
(0.168)\end{array}$ & ${ }^{*}$ \\
\hline Village Payout per Policy Three Years back (Rs. '000s) & $\begin{array}{c}0.172 * * \\
(0.066)\end{array}$ & $\begin{array}{l}0.17^{* *} \\
(0.078)\end{array}$ & $\begin{array}{c}0.044 \\
(0.077)\end{array}$ & $\begin{array}{l}0.28 * * * \\
(0.089)\end{array}$ & $\begin{array}{l}0.323 * * * \\
(0.096)\end{array}$ & $\begin{array}{c}0.168 * \\
(0.092)\end{array}$ & $\begin{array}{c}0.087 \\
(0.085)\end{array}$ & & $\begin{array}{c}0.133 \\
(0.089)\end{array}$ & & $\begin{array}{c}0.175 \\
(0.100)\end{array}$ & * & $\begin{array}{c}0.213 \\
(0.101)\end{array}$ & )$^{* *}$ \\
\hline Number of Households in Village who received a Payout Previous Year & & $\begin{array}{l}0.004 \text { *** } \\
(0.001)\end{array}$ & $\begin{array}{l}0.003^{* *} \\
(0.001)\end{array}$ & & $\begin{array}{c}0.001 \\
(0.001)\end{array}$ & $\begin{array}{c}0.002 \\
(0.001)\end{array}$ & & & $\begin{array}{c}0.004 \\
(0.001)\end{array}$ & $* * *$ & & & $\begin{array}{l}0.001 \\
(0.001)\end{array}$ & \\
\hline Number of Households in Village who received a Payout Two Years back & & $\begin{array}{c}0.002 \\
(0.001)\end{array}$ & $\begin{array}{c}0.001 \\
(0.001)\end{array}$ & & $\begin{array}{c}-0.001 \\
(0.002)\end{array}$ & $\begin{array}{c}0.001 \\
(0.002)\end{array}$ & & & $\begin{array}{c}0.001 \\
(0.001)\end{array}$ & & & & $\begin{array}{c}0.000 \\
(0.002)\end{array}$ & \\
\hline Number of Households in Village who received a Payout Three Years back & & $\begin{array}{c}-0.002 * \\
(0.001)\end{array}$ & $\begin{array}{l}-0.003 * * * \\
(0.001)\end{array}$ & & $\begin{array}{l}-0.003 * * \\
(0.001)\end{array}$ & $\begin{array}{c}-0.001 \\
(0.002)\end{array}$ & & & $\begin{array}{c}-0.003 \\
(0.001)\end{array}$ & ** & & & $\begin{array}{l}-0.003 \\
(0.001)\end{array}$ & * \\
\hline Revenue Lost Due to Crop Loss Previous Year (Rs. '0000s) & & $\begin{array}{l}-0.006 \\
(0.011)\end{array}$ & $\begin{array}{c}-0.008 \\
(0.010)\end{array}$ & & $\begin{array}{c}-0.02 * \\
(0.012)\end{array}$ & $\begin{array}{l}-0.022 \text { ** } \\
(0.009)\end{array}$ & & & $\begin{array}{l}-0.008 \\
(0.010)\end{array}$ & & & & $\begin{array}{l}-0.019 \\
(0.012)\end{array}$ & \\
\hline Revenue Lost Due to Crop Loss Two Years back (Rs. '0000s) & & $\begin{array}{l}-0.005 \\
(0.010)\end{array}$ & $\begin{array}{c}-0.004 \\
(0.011)\end{array}$ & & $\begin{array}{c}-0.021 \\
(0.015)\end{array}$ & $\begin{array}{c}-0.026 * * \\
(0.013)\end{array}$ & & & $\begin{array}{l}-0.006 \\
(0.010)\end{array}$ & & & & $\begin{array}{l}-0.026 \\
(0.014)\end{array}$ & * \\
\hline Revenue Lost Due to Crop Loss Three Years back (Rs. '0000s) & & $\begin{array}{c}0.006 \\
(0.007)\end{array}$ & $\begin{array}{c}0.007 \\
(0.007)\end{array}$ & & $\begin{array}{l}-0.005 \\
(0.011)\end{array}$ & $\begin{array}{c}-0.013 \\
(0.010)\end{array}$ & & & $\begin{array}{c}0.007 \\
(0.007)\end{array}$ & & & & $\begin{array}{l}-0.004 \\
(0.011)\end{array}$ & \\
\hline Mean Village Revenue Lost Due to Crop Loss Previous Year (Rs. '0000s) & & $\begin{array}{c}0.0822^{* *} \\
(0.035)\end{array}$ & $\begin{array}{c}0.062 \text { * } \\
(0.035)\end{array}$ & & $\begin{array}{c}0.064 \\
(0.065)\end{array}$ & $\begin{array}{c}0.062 \\
(0.053)\end{array}$ & & & $\begin{array}{c}0.056 \\
(0.034)\end{array}$ & & & & $\begin{array}{c}0.04 \\
(0.055)\end{array}$ & \\
\hline Mean Village Revenue Lost Due to Crop Loss Two Years back (Rs. '0000s) & & $\begin{array}{c}0.046 \\
(0.036)\end{array}$ & $\begin{array}{l}0.036 \\
(0.036)\end{array}$ & & $\begin{array}{c}0.034 \\
(0.057)\end{array}$ & $\begin{array}{c}0.045 \\
(0.044)\end{array}$ & & & $\begin{array}{c}0.044 \\
(0.034)\end{array}$ & & & & $\begin{array}{l}0.025 \\
(0.046)\end{array}$ & \\
\hline Mean Village Revenue Lost Due to Crop Loss Three Years back (Rs. '0000s) & & $\begin{array}{c}-0.029 \\
(0.026)\end{array}$ & $\begin{array}{c}-0.041 \\
(0.025)\end{array}$ & & $\begin{array}{c}-0.046 \\
(0.041)\end{array}$ & $\begin{array}{c}-0.039 \\
(0.038)\end{array}$ & & & $\begin{array}{l}-0.035 \\
(0.030)\end{array}$ & & & & $\begin{array}{l}-0.054 \\
(0.038)\end{array}$ & \\
\hline Number of Insurance Policies Bought Previous Year & & & $\begin{array}{l}0.048 \text { *** } \\
(0.007)\end{array}$ & & & $\begin{array}{l}-0.059 * * * \\
(0.007)\end{array}$ & $\begin{array}{c}0.009 \\
(0.010)\end{array}$ & & $\begin{array}{c}0.01 \\
(0.010)\end{array}$ & & $\begin{array}{c}-0.01 \\
(0.013)\end{array}$ & & $\begin{array}{l}-0.013 \\
(0.012)\end{array}$ & \\
\hline Number of Insurance Policies Bought Two Years back & & & $\begin{array}{c}0.01 \\
(0.006)\end{array}$ & & & $\begin{array}{l}-0.077^{* * *} \\
(0.008)\end{array}$ & $\begin{array}{c}0.004 \\
(0.009)\end{array}$ & & $\begin{array}{c}0.001 \\
(0.009)\end{array}$ & & $\begin{array}{l}-0.013 \\
(0.014)\end{array}$ & & $\begin{array}{l}-0.017 \\
(0.014)\end{array}$ & \\
\hline Number of Insurance Policies Bought Three Years back & & & $\begin{array}{c}0.004 \\
(0.006)\end{array}$ & & & $\begin{array}{l}-0.08 * * * \\
(0.009)\end{array}$ & $\begin{array}{c}0.01 \\
(0.010)\end{array}$ & & $\begin{array}{c}0.013 \\
(0.009)\end{array}$ & & $\begin{array}{l}-0.008 \\
(0.014)\end{array}$ & & $\begin{array}{l}-0.008 \\
(0.014)\end{array}$ & \\
\hline Individual Payout Received Previous Year (Rs. '000s) & & & $\begin{array}{c}0.056 \\
(0.034)\end{array}$ & & & $\begin{array}{c}0.02 \\
(0.040)\end{array}$ & $\begin{array}{c}0.036 \\
(0.060)\end{array}$ & & $\begin{array}{c}0.006 \\
(0.060)\end{array}$ & & $\begin{array}{c}0.106 \\
(0.071)\end{array}$ & & $\begin{array}{l}0.094 \\
(0.064)\end{array}$ & \\
\hline Individual Payout Received Two Years back (Rs. '000s) & & & $\begin{array}{c}0.103 * * * \\
(0.035)\end{array}$ & & & $\begin{array}{c}0.071 \\
(0.054)\end{array}$ & $\begin{array}{c}0.176 \\
(0.073)\end{array}$ & ** & $\begin{array}{c}0.166 \\
(0.076)\end{array}$ & ** & $\begin{array}{c}0.277 \\
(0.118)\end{array}$ & ** & $\begin{array}{c}0.264 \\
(0.112)\end{array}$ & ** \\
\hline Individual Payout Received Three Years back (Rs. '000s) & & & $\begin{array}{l}0.122{ }^{* * *} \\
(0.038)\end{array}$ & & & $\begin{array}{c}0.113 * \\
(0.059)\end{array}$ & $\begin{array}{c}0.117 \\
(0.062)\end{array}$ & * & $\begin{array}{c}0.08 \\
(0.077)\end{array}$ & & $\begin{array}{c}0.257 \\
(0.099)\end{array}$ & $* * *$ & $\begin{array}{c}0.244 \\
(0.087)\end{array}$ & *** \\
\hline Constant & $\begin{array}{c}0.5^{* * *} \\
(0.075)\end{array}$ & $\begin{array}{l}0.502 \text { *** } \\
(0.075)\end{array}$ & $\begin{array}{l}0.503 * * * \\
(0.070)\end{array}$ & $\begin{array}{l}0.264 * * * \\
(0.082)\end{array}$ & $\begin{array}{l}0.289^{* * *} \\
(0.082)\end{array}$ & $\begin{array}{c}0.377^{* * *} \\
(0.080)\end{array}$ & $\begin{array}{c}0.602 \\
(0.064)\end{array}$ & $* * *$ & $\begin{array}{c}0.636 \\
(0.064)\end{array}$ & $* * *$ & & & & \\
\hline $\begin{array}{c}\text { Cragg-Donald F-Stat } \\
\end{array}$ & & & & & & & 6.828 & & 6.646 & & 4.342 & & 4.313 & \\
\hline r2 & 0.156 & 0.166 & 0.204 & 0.193 & 0.201 & 0.276 & 0.168 & & 0.174 & & 0.158 & & 0.173 & \\
\hline $\mathrm{N}$ & 3681 & 3681 & 3681 & 3681 & 3681 & 3681 & 3681 & & 3681 & & 3681 & & 3681 & \\
\hline
\end{tabular}

Notes: Regressions include the portion of the sample for whom at least three years of history are available $(3681=2 * 989+2 * 649+405)$. The main conclusion of Tables 1 and 2 in the main text remain robust when run on the same restricted sample. The primary specification is in Column 10, which corresponds to Figure 1 in the main text. In the IV Specifications, all three lags of "Payout Received" and "Number of Insurance Policies Bought" are instrumented with the full set of marketing variables lagged three years, and the marketing variables interacted with village-level payouts. All specifications include year dummies, dummies for villages that entered the eperiment in different years, and the complete set of same-year marketing variables as additional controls. The OLS specifications also include three lags of marketing variables as controls. Errors clustered at village level. 
Appendix Table A6: Historical Average Insurance Experience

\begin{tabular}{|c|c|c|c|c|c|c|}
\hline & \multicolumn{3}{|c|}{ Pooled } & \multicolumn{3}{|c|}{ Individual Fixed Effects } \\
\hline & IV & IV & IV & IV & IV & IV \\
\hline & $(1)$ & $(2)$ & (3) & (4) & (5) & (6) \\
\hline \multirow[t]{2}{*}{ Historical Average Village Payout per Policy (Rs. '000s) } & $0.921^{* * *}$ & 0.187 & 0.052 & $3.495 * * *$ & $2.691 * * *$ & $2.59^{* *}$ \\
\hline & $(0.200)$ & $(0.292)$ & $(0.284)$ & $(0.640)$ & $(1.006)$ & $(1.024)$ \\
\hline \multirow[t]{2}{*}{ Historical Average Total Individual Payout (Rs. '000s) } & & $0.388 * * *$ & $0.354 * * *$ & & 0.056 & 0.051 \\
\hline & & $(0.121)$ & $(0.123)$ & & $(0.143)$ & $(0.140)$ \\
\hline \multirow[t]{2}{*}{ Historical Average Total Individual Policy Units Bought (Rs. '000s) } & $0.143 * *$ & $-0.168 *$ & $-0.18 * *$ & 0.008 & -0.147 & -0.131 \\
\hline & $(0.056)$ & $(0.088)$ & $(0.085)$ & $(0.054)$ & $(0.102)$ & $(0.096)$ \\
\hline \multirow[t]{2}{*}{ Village Payout per Policy in Previous Year (Rs. '000s) } & -0.001 & 0.011 & 0.013 & 0.001 & 0.008 & 0.009 \\
\hline & $(0.009)$ & $(0.010)$ & $(0.010)$ & $(0.009)$ & $(0.013)$ & $(0.012)$ \\
\hline \multirow[t]{2}{*}{ Individual Payout Received Previous Year (Rs. '000s) } & & $1.039 * * *$ & $0.938 * * *$ & & $1.252 * *$ & $1.169 * *$ \\
\hline & & $(0.312)$ & $(0.314)$ & & $(0.604)$ & $(0.569)$ \\
\hline \multirow[t]{2}{*}{ Number of Insurance Policies Bought Previous Year } & & -0.011 & -0.004 & & -0.087 & -0.088 \\
\hline & & $(0.033)$ & $(0.033)$ & & $(0.078)$ & $(0.075)$ \\
\hline \multirow[t]{2}{*}{ Number of Households in Village Who Received a Payout Previous Year } & & & $0.003 * * *$ & & & 0.001 \\
\hline & & & $(0.001)$ & & & $(0.001)$ \\
\hline \multirow[t]{2}{*}{ Revenue Lost Due to Crop Loss Previous Year (Rs. '0000s) } & & & -0.007 & & & $-0.019 *$ \\
\hline & & & $(0.009)$ & & & $(0.011)$ \\
\hline \multirow[t]{2}{*}{ Mean Village Revenue Lost Due to Crop Loss Previous Year (Rs. '0000s) } & & & $0.063 * *$ & & & 0.044 \\
\hline & & & $(0.029)$ & & & $(0.046)$ \\
\hline \multirow[t]{2}{*}{ Constant } & $0.676 * * *$ & $0.649 * * *$ & $0.63 * * *$ & & & \\
\hline & (0.059) & $(0.060)$ & $(0.058)$ & & & \\
\hline Cragg-Donald F-Stat & 9.134 & 5.905 & 5.883 & 6.926 & 4.212 & 4.193 \\
\hline r2 & 0.147 & 0.166 & 0.172 & 0.173 & 0.171 & 0.174 \\
\hline $\mathrm{N}$ & 3681 & 3681 & 3681 & 3681 & 3681 & 3681 \\
\hline
\end{tabular}

Notes: This table compares the effect of recent (single year lag) payouts and historical payout experience. We define the "Historical Average Village Payout," as the

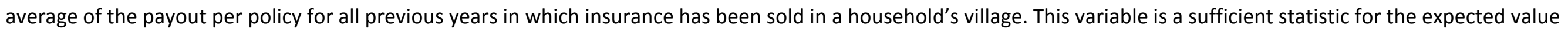

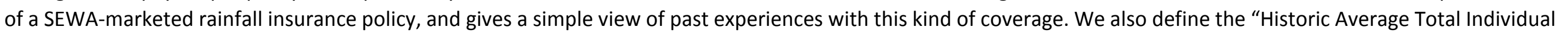
Payout", which is the average payout received by each household over all previous years in which insurance has been sold in a household's village. Regressions include

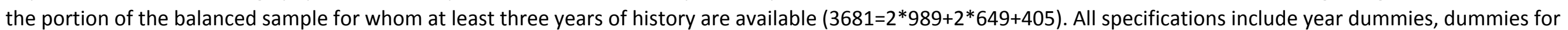
villages that entered the experiment in different years, and the complete set of same-year marketing variables as additional controls. In the IV Specifications, "Payout Recevied Previous Year" and "Number of Insurance Policies Bought Previous Year" are instrumented with the full set of marketing variables lagged three years. Standard errors are clustered at village level. 
Appendix Table A7: Marketing Variables and Instruments

\begin{tabular}{|c|c|c|c|c|c|c|c|c|c|}
\hline Marketing Variables/Instruments & Description & 2006 & 2007 & 2008 & 2009 & 2010 & 2011 & 2012 & 2013 \\
\hline$\overline{\text { mrkt_allnegative }}$ & Negative Marketing Flyer & $x$ & & & & & & & \\
\hline mrkt_poslang & Positive Marketing Flyer & $\mathrm{x}$ & & & & & & & \\
\hline mrkt_posimg & Positive Imagery Flyer & $\mathrm{x}$ & & & & & & & \\
\hline discount & Fixed Price Discount & & $\mathrm{x}$ & $\mathrm{x}$ & & & & & \\
\hline discountsq & Fixed Price Discount Squared & & $x$ & $x$ & & & & & \\
\hline groupT & Group Promotion Flyer & & $\mathrm{x}$ & & & & & & \\
\hline muslimT & Muslim Imagery Flyer & & $x$ & & & & & & \\
\hline hinduT & Hindu Imagery Flyer & & $x$ & & & & & & \\
\hline sewaT & Sewa Brand Stress Flyer & & $x$ & & & & & & \\
\hline peerT & Peer Group Flyer & & $\mathrm{x}$ & & & & & & \\
\hline рраут & Positive Payout Likelihood Flyer & & $\mathrm{x}$ & & & & & & \\
\hline pframeT & Safety Frame Flyer & & $x$ & & & & & & \\
\hline vframeT & Vulnerability Frame Flyer & & $\mathrm{x}$ & & & & & & \\
\hline rebate_50percentoff & Buy 1 get $150 \%$ Off & & & $x$ & & & & & \\
\hline rebate2_1free & Buy 2 Get 1 Free & & & $x$ & & & & & \\
\hline rebate3_1free & Buy 3 Get 1 Free & & & $\mathrm{x}$ & & & & & \\
\hline flyer_hyv & HYV Complementarity Flyer & & & $x$ & & & & & \\
\hline assigned_risk_ws & Risk Worksheet & & & $x$ & & $x$ & & & \\
\hline flyer_hyv_exp & HYV Flyer and Risk Worksheet & & & $x$ & & & & & \\
\hline bdmperc & BDM Offer (as percentage of List Premium) & & & & $x$ & $x$ & $x$ & $x$ & $x$ \\
\hline disc4game & BDM Game for 4 Policies & & & & $x$ & $x$ & $x$ & $x$ & $x$ \\
\hline fourbdmperc & BDM Offer X Offered BDM for 4 Policies & & & & $x$ & $x$ & $x$ & $x$ & $x$ \\
\hline bdmpercX2010 & BDM Offer (as percentage of List Premium) X 2010 & & & & & $x$ & & & \\
\hline disc4gameX2010 & BDM Game for 4 Policies X 2010 & & & & & $x$ & & & \\
\hline fourbdmpercX2010 & BDM Offer X Offered BDM for 4 Policies X 2010 & & & & & $x$ & & & \\
\hline assigned_video_test & Peer Group Video & & & & & $x$ & & & \\
\hline assigned_drought_flyer & Drought Flyer & & & & & $x$ & & & \\
\hline assigned_subsidies_flyer & Subsidies Flyer & & & & & $x$ & & & \\
\hline assigned_loan & BDM Game (Loan Bundling) & & & & & $\mathrm{x}$ & & & \\
\hline
\end{tabular}

Notes: This table lists all of the marketing variables and indicates the years in which they were implemented experimentally. A more detailed description of the marketing interventions can be found in the online appendix text. Interactions of BDM game and a 2010 dummy is due to the fact that the BDM game was played in 2010 for double the amount of policies as in other years, due to the NABARD subsidy. 


\section{A8. Details of Marketing Treatments}

Table A7 reports the household-level marketing variants that were implemented each year. This section elaborates. For more details on the 2007 experiments, see Cole et al. (2013). Since this paper is part of a larger project on rainfall insurance, some explanatory material and much additional analysis of these experiments and the insurance impacts is reserved for future work.

Flyers: Some participants received flyers with information about insurance as part of their marketing visits. These flyers incorporated the following manipulations.

Negative vs Positive Language/Imagery: Positive flyers described insurance as "providing protection and security" with information showing the maximum payout that would have been received under the policy in the previous decade. Negative flyers described insurance as helping "to avoid catastrophe and negative information" and showed the average payout that would have been received over the past decade.

Positive vs Average Information: Positive information flyers showed the maximum payout that would have been received under the policy in the previous decade. Average information flyers showed the average payout that would have been received over the past decade.

Drought versus Bounty: Bounty flyers showed farmers standing in front of a bountiful harvest, while drought flyers showed farmers in fron of a drought-scorched field.

Subsidies: In 2010, Nabard was subsidizing the policies with a 'buy one get one free' offer. Households were told that due to this offer, the expected payout would exceed the list price of Rs. 150.

Group vs Individual: The group flyer emphasized the value of the policy for the purchaser's family, while the individual flyer emphasized the value for the individual.

Religion (Hindu, Muslimm, or Neutral): These flyers provided group identity cues. A photograph on the flyer depicted a farmer in front of a Hindu temple (Hindu Treatment), a mosque (Muslim Treatment), or a nondescript building. The farmer has a matching first name, which is characteristically Hindu, characteristically Muslim, or neither.

High-Yielding Varieties (HYV): HYV flyers explained that rainfall insurance might complement adoption of HYV seed varieties which are sensitive to extreme weather.

Risk Exposure Worksheet: In this treatment, households were told about the relationship between the size of landholding and amount of insurance coverage. The flyer included a worksheet section, where SEWA's insurance representative worked through simple calculations with the household, in order to recommend the number of units of insurance coverage to buy.

Videos: Some participants were shown videos with information about insurance as part of their marketing visits. These videos had the following manipulations. 
SEWA Brand: In the "Strong SEWA brand" treatment, videos emphasized that the product was marketed and endorsed by SEWA.

Peer/Authority Figure: In the peer treatment, a product endorsement was delivered by a local farmer, while in the authority treatment it was delivered by a teacher.

Payout ("2/10" vs "8/10"): In the "2/10" treatment, households were told "the product would have paid out in approximately 2 of the previous 10 years". In the " $8 / 10$ " frame they were told that the product would not have paid out in approximately 8 of the previous 10 years.

Safety or Vulnerability: The "Safety" treatment described the benefits of insurance in terms of it being something that will protect the household and ensure prosperity. The "Vulnerability" treatment warned the household of the difficulties it may face if it does not have insurance and a drought occurs.

Peer(s) Video: In this treatment, households were shown interviews of farmers in the study who purchased weather insurance in previous years and were happy with the product.

Fixed Price Discounts: Here, households were randomly assigned fixed price discount(s) of either Rs. 5, $15,30,60$ or 90 on purchase of an insurance policy. These were delivered through a coupon or scratch card.

Discounts for Higher Coverage: This treatment offered discounts for purchasing multiple policies. The discounts were: buy 2 get one free, buy 3 get one free, or buy one get the second $50 \%$ off.

Willingness to Pay / BDM: We used an incentive-compatible Becker-DeGroot-Marschak mechanism to measure respondents' willingness to pay (WTP) for insurance policies. Households were randomly assigned to report their maximum WTP for one policy or for a bundle of four policies. Once this "bid" is recorded, the BDM offer price is revealed. If the offer price turns out to be less than the respondent's bid, the respondent is expected to purchase the policy at the revealed offer price. If the offer turns out to be more than the bid, the respondent doesn't get a chance to purchase the policy at the offer price. Purchases at full price were permitted at any time. In 2010, some households were randomly assigned BDM incentive-compatible elicitation with premium payment due in November (i.e., the insurance premium could be borrowed). 


\section{A9. Sample Termsheets}

Index-based rainfall insurance policy marketed by SEWA in Sanand taluka of Ahmadabad district in 2012; Insurer - AIC:

\section{RAINFALL INDEXED CROP INSURANCE (KHARIF 2012)} TERM SHEET

State: GUJ

District: Ahmadabad

Block: Sanand

\begin{tabular}{|c|r|l|l|}
\hline Crop: $\mid$ Generic & Reference Weather Station:| & & \\
\hline
\end{tabular}

1. DEFICIT RAINFALL

\begin{tabular}{|l|l|l|}
\hline \multirow{4}{*}{$\begin{array}{l}\text { RAINFALL } \\
\text { VOLUME }\end{array}$} & PERIOD & 16-Jun to \\
\cline { 2 - 3 } & INDEX & Aggregate of rainfall over respec \\
\cline { 2 - 3 } & STRIKE I (<) & 60 \\
\cline { 2 - 3 } & STRIKE II (<) & 25 \\
\cline { 2 - 3 } & EXIT & 0 \\
\cline { 2 - 3 } & RATE I (Rs./ mm) & 2.5 \\
\hline & RATE II (Rs. $/ \mathrm{mm})$ & 10.50 \\
\hline & MAXIMUM PAYOUT (Rs.) & 350 \\
\hline
\end{tabular}

TOTAL MAXIMUM PAYOUT (Rs.)

(1

$\mathrm{mm}$ and if the rainfall in a day is less than

1000

Note: In case of Deficit cover, Daily maximum rainfall is capped at will be not counted in rainfall volume under this cover.

\begin{tabular}{|c|c|c|c|c|c|}
\hline \multicolumn{3}{|c|}{ TTIAUL-O } & \multicolumn{3}{|c|}{ PHASE - III } \\
\hline 16-Jul & to & 20-Aug & 21-Aug & to & 30-Sep \\
\hline \multicolumn{6}{|l|}{ hases } \\
\hline 100 & $\mathrm{~mm}$ & & 30 & $\mathrm{~mm}$ & \\
\hline 50 & $\mathrm{~mm}$ & & 10 & $\mathrm{~mm}$ & \\
\hline 0 & & & 0 & & \\
\hline 2 & & & 3 & & \\
\hline 6.00 & & & 19.00 & & \\
\hline 400 & & & 250 & & \\
\hline
\end{tabular}

400

250

\begin{tabular}{|c|c|c|c|c|}
\hline \multirow{6}{*}{$\begin{array}{l}\text { EXCESS RAINFALL } \\
\text { (Single Payout) }\end{array}$} & \multirow{2}{*}{\begin{tabular}{|l|} 
PERIOD \\
INDEX \\
CTRIKE
\end{tabular}} & $\begin{array}{r}\text { PHAS } \\
\text { to }\end{array}$ & PHASE - I & \multirow[b]{2}{*}{ consecutive day's cumulative rainfall in respective Phases } \\
\hline & & Maximum of & 7 & \\
\hline & STRIKE (>) & 375 & $\mathrm{~mm}$ & \\
\hline & EXIT & 575 & $\mathrm{~mm}$ & \\
\hline & RATE (Rs/mm) & \multicolumn{2}{|l|}{2.50} & \\
\hline & MAXIMUM PAYOUT (Rs) & \multicolumn{2}{|l|}{500} & \\
\hline & TOTAL PAYOUT (Rs.) & \multicolumn{2}{|l|}{500} & \\
\hline & SUM INSURED (Rs.) & \multicolumn{2}{|l|}{2000} & \\
\hline & PREMIUM WITH S. TAX (Rs.) & \multicolumn{2}{|l|}{200} & \\
\hline & PREMIUM \% & \multicolumn{2}{|l|}{$10.00 \%$} & \\
\hline
\end{tabular}




\section{Agriculture Insurance Company of India Ltd.}

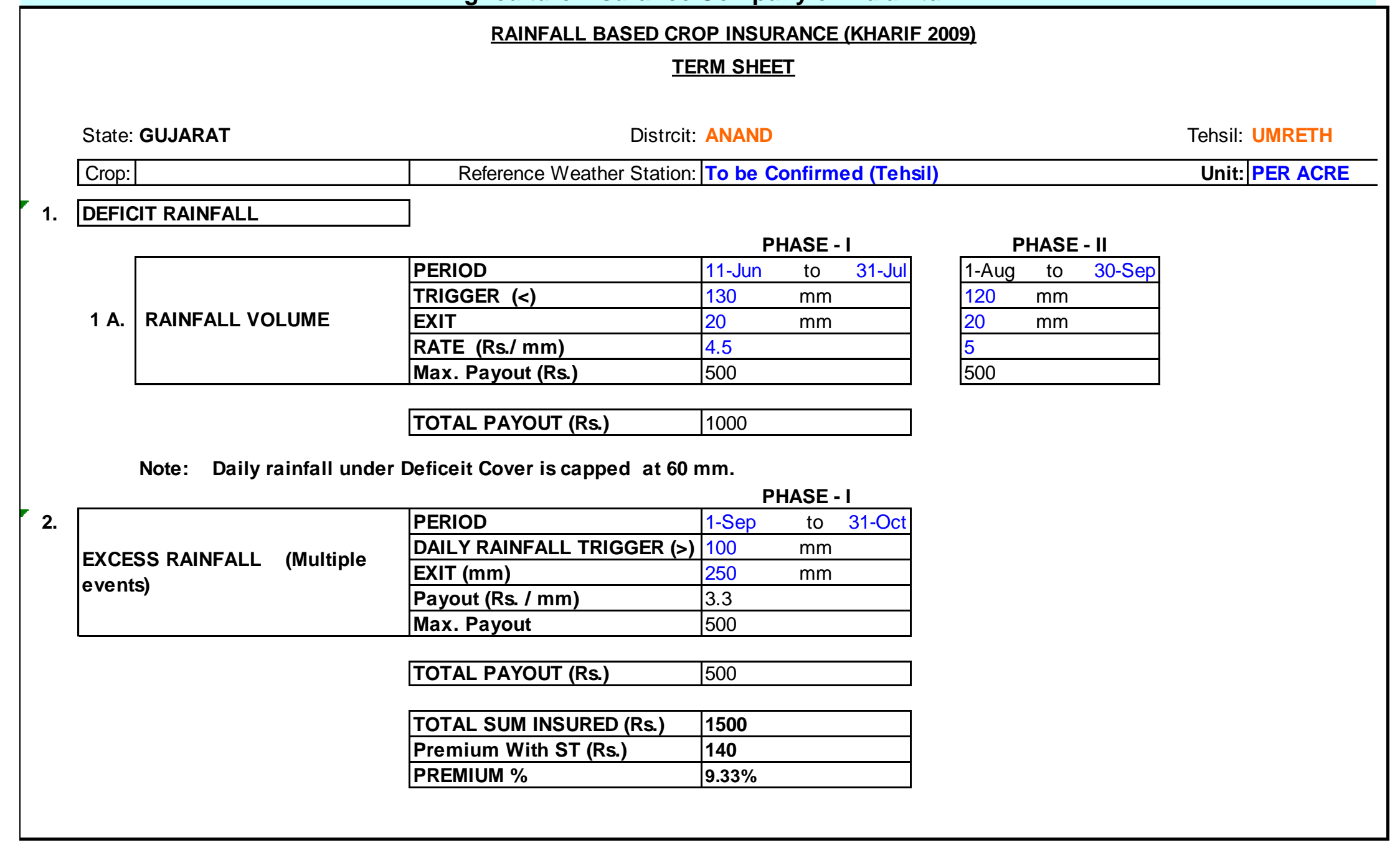


Index-based rainfall insurance policy marketed by SEWA in Patan district in 2006; Insurer - ICICI:

\section{TERMSHEET FOR WEATHER INDEX INSURANCE}

\section{Product Reference}

Crops

Reference Weather Station

Index
PT06

Any crop in the district

Patan

Aggregate rainfall during the cover phases in $\mathrm{mm}$.

If rainfall on a day is $<2 \mathrm{~mm}$ it is not counted in the aggregate rainfall

If rainfall on a day is $>60 \mathrm{~mm}$ it is not counted in the aggregate rainfall

Above condition applicable only for deficit rainfall cover and not for excess

rainfall cover

Calendar day in the month of June 2006 when cumulative rainfall for the If above condition is not met in June, Policy invariably starts on June 25

Definition of Day 1

\section{0 days}

\begin{tabular}{|c|c|c|c|}
\hline Cover Phase & I & II & III \\
\hline Duration & 35 days & 35 days & 40 days \\
\hline \multicolumn{4}{|c|}{ PUT } \\
\hline Strike $(\mathrm{mm})<$ & 100 & 75 & - \\
\hline Exit $(\mathrm{mm})<$ & 10 & 5 & - \\
\hline Notional (Rs / mm) & 5.00 & 5.00 & - \\
\hline Policy Limit (Rs) & 500 & 500 & - \\
\hline \multicolumn{4}{|c|}{ CALL } \\
\hline Strike $(\mathrm{mm})>$ & - & - & 550 \\
\hline Exit $(\mathrm{mm})>$ & - & - & 650 \\
\hline Notional $(\mathrm{Rs} / \mathrm{mm})$ & - & - & 5.00 \\
\hline Policy Limit (Rs) & - & - & 500 \\
\hline Observed Index & 0 & & \\
\hline Claims Payable & 500 & 500 & 500 \\
\hline
\end{tabular}

\section{Data Source}

Settlement Date

\section{NCMSL}

Thirty days after the data release by NCMSL and verified by Insurer.

- The quantity of rainfall received on Day 1 is divided into two parts: Policy Activation Rainfall and Index Rainfall. Policy Activation Rainfall is the quantity of rainfall that contributes towards the requirement of first $50 \mathrm{~mm}$ rainfall condition and In 